\title{
Compatibility of Firm Positioning Strategy and Website Content: Highest R\&D Spending Firms in Turkey
}

\section{Firma Konumlandırma Stratejisinin Web Sitesi İçeriği ile Uyumluluğu: Türkiye'de En Yüksek Ar\&Ge Harcaması Yapan Firmalar}

\author{
Evla MUTLU KESİCi ${ }^{*}$ \\ Murat NAZLI** \\ Gönenç DALGIÇ TURHAN****
}

\begin{abstract}
Corporate websites are essential platforms through which firms introduce their goods and services on B2B and $\mathrm{B} 2 \mathrm{C}$ level, express financial information for the stakeholders and share corporate values, purposes and activities. Due to its facilities, websites take part in firm positioning strategy. Accordingly this study aims to understand the innovation oriented positioning through corporate websites. The method applied in this study has been adapted from the 2QCV2Q Model developed by Mich and Franch (2000) to evaluate websites and top 30 firms with the highest Research and Development expenditures listed in Turkishtime (2015) have been analyzed. Within this context, this study presents a revised and updated method for the assessments of websites through positioning strategy framework. Findings indicate no direct relationship between website evaluation and R\&D expenditure, though some common weaknesses have been put forward, such as information about management of the firms. Besides, publicly traded firms are recognized to facilitate websites more efficiently than non-publicly traded firms. Study contribute to both academia and practitioners as putting forward a new approach for 2QCV2Q Model and indicating the similarities and differences among the corporate websites through positioning perspective.
\end{abstract}

Keywords: Innovation, Positioning, Website Evaluation, Turkey, Research\&Development

$\ddot{O} z$

Kurumsal web siteleri, firmaların ürünlerini ve hizmetlerini kurumlara ve son tüketiciye tanıttı̆̆ı, paydaşlar için finansal bilgileri açıkladığı, kurumsal değerlerini, amacını ve etkinliklerini paylaştığı önemli platformlardır. Sağladığı faydalar sebebiyle, web siteleri konumlandırma stratejilerinin bir parçasıdır. Bu nedenle, bu çalışma inovasyon odaklı konumlandırmayı anlamayı amaçlamaktadır. Çalışmada, Mich ve Franch (2000) tarafından geliştirilen 2QCV2Q modeli web sitelerini değerlendirmek için uyarlanmıştır ve Turkishtime 2015 sıralamasında Ar-Ge'ye en fazla harcama yapan ilk 30 firmanın web siteleri incelenmiştir. Bu bağlamda, bu çalışma, konumlandırma stratejisi çerçevesinde web sitelerini değerlendirmek için gözden geçirilmiş ve güncellenmiş bir yöntem sunmaktadır. Bulgular, web sitesi değerlendirmesi ile Ar\&Ge harcamaları arasında doğrudan bir ilişki olmadığını göstermekle birlikte; web sitesine yönelik bazı ortak zayıf noktaları ortaya çıkartmaktadır; örneğin yönetim alanında. Ayrıca, halka açık şirketlerin, halka açık olmayanlara kıyasla, web sitelerinden içerik açısından daha etkin faydalandığı görülmektedir. Çalışma, 5N1K modeli için yeni bir yaklaşım önermesi ve web sitelerinin benzerlik ve farklılıklarını konumlandırma çerçevesinden ortaya koyması açısından, hem akademisyenlere hem de uygulayıcılara katkıda bulunmaktadır.

Anahtar Kelimeler: Yenilik, Konumlandırma, İnternet Sitesi Değerlendirme, Türkiye, Ar-Ge

\section{Introduction}

Internet and World Wide Web have changed the way of working, thinking, and communicating. Internet also plays a significant role in strategic positioning (Favre-Bonte and Tran, 2015), so as the websites (Simeon, 1999). As indicated by Pollach (2011), corporate websites are "for the purpose of presenting the organization to external stakeholder groups such as customers, investors or press" so work as "the control of information flow in support

\footnotetext{
*PhD Candidate, Yaşar University, Dept. of Business, eevlamutlu@gmail.com

** Dr., Lecturer, Yaşar University, Dept. of Tourism Management, nazli.murat@gmail.com

${ }^{* * *}$ PhD Candidate, Yaşar University, Dept. of Business Engineering, gonencdalgic@gmail.com
}

Kesici, E , Nazlı, M , Turhan, G . (2017). Firma Konumlandırma Stratejisinin Web Sitesi İçeriği ile Uyumluluğu: Türkiye'de En Yüksek Ar\&Ge Harcaması Yapan Firmalar. Gaziantep University Journal of Social Sciences, 16 (3), 664-686. DOI: $10.21547 /$ jss.311944 
of corporate image strategies" (Sullivan, 1999). Websites are also expected to provide high quality service for customer loyalty (Chuang et al., 2016) and may increase the customer dependence (Obal and Kunz, 2013). Correspondingly in business, a large number of firms facilitate websites which affects consumer satisfaction (Kim and Stoel, 2014; Faizan, 2016), business performance (Lee and Kozar, 2006) and purchase intention (Wells et al., 2011), all implying the importance of website quality on stakeholder's decision. Chen et al. (2017) observing buyers" loyalty in e-commerce websites, offer sellers to improve "their cognitive and structural capital with buyers through providing appropriate website quality", indicating that social capital is also built via websites.

Since websites play a crucial role, various studies examine corporate websites from different perspectives such as; website usability (Huang and Cappel, 2012), web based public relations (Kim et al., 2010b), website design (Jones and DeGrow, 2011; Jones, 2015), website accessibility (Al-Mouh and Al-Khalifa, 2016; Loiacono et al., 2009; Romano, 2002), meeting media/journalist needs (Coy, 2003), characteristics of e-commerce user-interface (Zhao et al., 2006), marketing communications (Perry and Bodkin, 2002), sustainable information published in websites (Kunz and Ratliff, 2014), e-recruiting for human resources (Lee, 2005; Young and Foot, 2005), home page content and purpose (Liu et al., 1997), privacy policies (Liu and Arnett, 2002), environmental responsibility (Kim et al., 2010a), corporate social responsibility (Smith and Alexander, 2013; Tang et al., 2015), brand equity (Argyriou et al., 2006), corporate identity communication (Mohammed et al., 2016) and systems offering high quality information (Edelweis et al., 2011). Besides only a few studies focus on strategic positioning via websites. For instance, Simeon (1999) analyzes websites via a novel approach which is composed of four subjects; attracting, informing, positioning, and delivering (AIPD). According to Simeon, "web site design, transaction types, market targeting, community relations, and links to domestic and international activities" analysis can be used for the evaluation of website positioning strategy. Though, as website content is examined through positioning strategy, this paper is more positioning oriented.

On the other hand, innovation is essential for organizational survival and the value gathered through innovation is presented in terms of sales, profits, and growth (Cooper, 1984). Thus, high research and development (R\&D) spending is accepted as a driver for organizational innovativeness. From this point of view, this article analyzes the top 30 firms with the highest $R \& D$ expenditure and thus recognizes those firms having innovation oriented positioning strategy. In order to evaluate the firm's innovative oriented positioning in the market, a website is a less-recognized-tool respectively.

Besides, innovation oriented positioning strategy do not intend an innovative firm. There are several tools that measure organizational innovativeness and criteria are mainly composed of several issues such as intellectual property, qualified human resources, capacity of R\&D departments, R\&D expenditure (Bulut et al., 2013). Considering the complexity in innovation measurement, innovation-focused strategic positioning of the website does not necessarily indicate an innovative firm.

The evaluation of the firm website is not a new approach, although not evaluated to understand firm innovation oriented positioning strategy. The fundamental aim of this study is to evaluate the strategic positioning of high R\&D spending firms in Turkey as listed in Turkishtime (2015) through corporate websites.

\section{How to Evaluate Corporate Websites}

Since websites include multilevel data, evaluation may be carried through different perspectives and samplings. There are several methodologies offered in literature such as content analysis (Kwon and Jeong, 2015), analytic hierarchical process (Bulíček and Drdla, 
2015; Ecer, 2014), benchmarking (Johnson and Misic, 1999), decision tree (Sun et al., 2015), balanced scorecard (Kline et al., 2004), quality function deployment (Gonzalez et al., 2015), delphi method (Leite et al., 2014) etc. Though, no agreed method exists (Sun et al., 2015; Law and Buhalis, 2010).

Sun et al. (2015) listed methods offered for travel and tourism-related websites. According to this list besides methodology; dependent and independent variables, target sample and unit of analysis diversify through studies. Moreover, some researchers focus on the perception of customers, while some evaluate a website through tangible facilities offered by the website. For instance, Williamson et al. (2010) analyzed corporate websites from the applicant's point of view to comprehend its attractiveness, where results indicated that applicant's perspective is positively affected by the amount of company and job related information and website vividness. On the other hand, the study by Usta (2007) evaluated the largest 100 firms listed by Istanbul Chamber of Commerce in Turkey regarding the marketing channels used in websites and comparing sectors.

This study is not interested in customer perspective, instead of this, firm website is analyzed through a tangible perspective. Besides, this study facilitates a model offered by Mich and Franch (2000) to analyze websites, while the model is revised.

\section{Dimensions of Website Evaluation}

Since there are various sectors, there are also several websites specialized for different purposes. Some researchers focus on the evaluation of websites serving in a specific area such as e-commerce (Kang et al., 2016), travel and tourism (Law and Bhalis, 2010; Cengiz and Akkuş, 2015), sports (Chiu and Won, 2016), logistics (Bulíček and Drdla, 2015; Jain and Rangnekar, 2015) and health (Raj et al., 2016). Websites are evaluated according to various criteria which are sector specific for some cases. For instance, Liu et al. (2000) observes the quality dimensions of e-commerce websites under the topic of information, learning capability, playfulness, system quality, system use and service quality. Observing hotel websites, Chung and Law (2003) define dimensions to be; facilities information, customer contact information, reservation information, surrounding area information and management of website. There are also various studies related to tourism, offering several evaluation methodologies (Murphy et al., 1996). Apart from sectoral diversion, for some cases, website evaluation dimensions are offered for a general purpose such as Bai et al. (2008), defining two major classifications of website quality; functionality and usability. In this model, functionality is composed of purchase information, service/product information, destination information, quality of information and contact information where usability is composed of language, layout and graphics, information architecture, user interface-navigation, general (Bai et al., 2008).

Due to having divergent scales in evaluating the website, the model of Mich and Franch (2000) is used because of its convenience and functionality. The model, called 2QCV2Q Model (also known as $5 \mathrm{~W} 1 \mathrm{H}$ ), covers a wide range of facilities of websites, and composed of six dimensions:

- Identity (Who): A site with a strong brand identity remains impressed on the minds of those who visit it and forcefully conveys the company's image. The existence of an organization chart, corporation logo, vision/mission statement, company history and message from CEO are considered as the indicators of dimension of identity.

- Content (What): Content is evaluated in terms of the site's coverage of its domain according to the requirements of the user. Links (available services), product information, coverage (innovation related information), quality certificates, information related with customers, suppliers, references, news from new products/services, press 
releases, issues related social responsibility, environment sustainability reports, financial information, annual report.

- Service (Why): The functions offered by the site are evaluated from the perspective of the users. Email, newsletter, FAQ, human resources/employment opportunities, customer service/support.

- Location (Where): This dimension concerns both the reachability of a site and the ability of the user to interact with the host and also with the other users. Reachability of site, contact information, social media use (LinkedIn, Facebook, Instagram, Twitter, Google Plus, YouTube, blog, journal or periodical or press release).

- Management (When): Management of a site involves updating the information that it provides. Update (proper functioning and operability of website), currency of dates, tools, broken links.

- Usability (How): The last dimension of the model concerns all the aspects, which enable relatively undemanding use of site in terms of time or cognitive input. Evaluation starts with the hardware and software requirements to access the website. It is expected to reach the website by any internet browser and that it doesn't require unnecessary plugins. Other components are accessibility, hardware and software requirements, sitemap/table of contents, people with disabilities, search engine, language options.

The application of the model is not defined in standardized rules, which makes it possible to adapt the scale for this study, from a sample-focused perspective. Kamanlioglu and Emiroglu (2009) also analyzed the corporate websites in fishery sector, using 2QCV3Q model, modifying and adding a new dimension as "feasibility", while removing "location" from the adapted model. Distinctly, this classification includes some other dimensions such as; product size information, product packaging information and product cycle, online guest book/comment or order form, links to other related sites, back to the top of the page link, consistent page hierarchy, download section, printing of pages available etc. (Kamanlioglu and Emiroglu, 2009).

\section{Purpose of Research}

\section{Methodology}

The primary purpose is to present an evaluation of website positioning strategy through an improved assessment tool of firms with the highest amount of R\&D expenditure in Turkey as listed in Turkishtime (2015). Besides, the main characteristics, similarities and differences of websites have been analyzed and taken into account the sectoral diversity.

\section{Research Questions}

Throughout this research, the answers of three fundamental questions are investigated meticulously. Through the corporate websites of the firms, the primary questions are addressed below:

1. What are the characteristics of the corporate websites of the firms with the highest R\&D expenditures in Turkey?

2. What are the similarities and differences of these corporate websites?

3. What factors or characteristics come into prominence in the evaluation of these corporate websites through positioning strategy perspective? 


\section{Sample and Method}

The sample size consists of the thirty most innovative firms in Turkey announced by "Turkishtime R\&D 250" list in 2015, based on their R\&D spending. In order to comprehend these top 30 firms, in-depth analysis of firm's corporate websites is carried, based on the adapted model of Mich and Franch (2000). Table 1 in the following section represents the previous model and the adapted model for the researched corporate firms. Corporate websites of the firms are analyzed related to six dimensions of the model. The google search engine allows searching for keywords in a particular website. Google research engine is also facilitated related to some keywords linked to the dimension.

Two of the firms are recognized to be not operating anymore, so the sample size became 28. Additionally, by filling the contact form of each firm in their websites, a general question about what type of innovative activities they have in their firms, is sent to twenty eight firms to determine their attention to customer requests and speed of return. Although, five of all firms sent an auto-reply stating that they will contact us soon, only three of the firms sent a special reply in the following month after sending the contact form.

The dimensions are composed of various number of sub-indicators, each of them are nominal variables. Level of categorization for sub-indicators is the same within one dimension and it is coded as 0-1-2 shown in Appendix 1. Only for two dimensions namely "location" and "management", the categorization is presented as $0-1$ due to the special feature and selfdefinition of these sub-indicators. Thus, some dimensions are composed of two level categorized sub-indicators, while some are three level categorized, where the research of Kamanlioglu and Emiroğlu (2009) used only two level (0 and 1) categorization for evaluation.

Summing up the evaluation value of dimensions for firm ' $\mathrm{f}$ ', result in having a total website evaluation degree $\left(\mathrm{T}_{\mathrm{f}}\right)$. In order to calculate $\mathrm{T}_{\mathrm{f}}$, six dimensions are calculated considering the sub-indicators. Since there are six dimensions in the model, $\mathrm{T}_{\mathrm{f}}$ is calculated according to the evaluations of each dimension (D). Considering the dimension "Identity", the value of Identity (DIdentity) is calculated according to the evaluation of its sub-indicators. Each dimension is composed of $\mathrm{k}$ number of sub-indicators, where $\mathrm{k}$ is equal to 6 for the dimension Identity $\left(\mathrm{k}_{\text {Idendity }}=6\right)$ as seen in Table 1 .

Table 1: Sample evaluation of the dimension "Identity" for the firm Q

\begin{tabular}{|c|c|c|c|c|c|c|}
\hline $\begin{array}{c}\text { Firm } \\
\text { Name }\end{array}$ & $\begin{array}{c}\text { Organizational } \\
\text { chart }\end{array}$ & $\begin{array}{c}\text { Corporation } \\
\text { logo }\end{array}$ & $\begin{array}{c}\text { Vision- } \\
\text { mission } \\
\text { statement }\end{array}$ & $\begin{array}{c}\text { Company } \\
\text { history }\end{array}$ & $\begin{array}{c}\text { Board of } \\
\text { Directors }\end{array}$ & $\begin{array}{c}\text { Message from } \\
\text { Top } \\
\text { Management }\end{array}$ \\
\hline $\mathrm{Q}$ & 2 & 1 & 2 & 0 & 2 & 1 \\
\hline
\end{tabular}

In order to evaluate the firm's degree in dimension Identity (DIdentity), one should consider the level of categories in the sub-indicators of Identity. For instance, indicators in Identity are evaluated in three levels $(0,1$ and 2$)$, though sub-indicators of Location is evaluated in two levels $(0$ and 1$)$. For the case of Identity, since there are three categories, $\mathrm{c}$ is equal to 3 $\left(c_{\text {identity }}=3\right.$ ), for the case of Location, $\mathrm{c}$ is equal to 2 (clocation $=2$ ).

In order to calculate the $\mathrm{D}$ value, possible maximum value indicating the value of a dimension for highest rated sub-indicators, is evaluated as $(\mathrm{c}-1)^{*} \mathrm{k}$. Observing the dimension Identity, assume that all sub-indicators are rated with the highest value they can have, which is 2 in this case. All sub-indicators getting the value of 2 , means a total value of $2 * 6$, which is equal to 12 . This means possible maximum value is calculated as $(\mathrm{c}-1) * \mathrm{k}=(3-1) * 6$, which is 
equal to 12 for dimension Identity. So the level of each sub-indicator affects the evaluation of $\mathrm{D}$, therefore $\mathrm{T}$ values.

On the other actual value of dimension is calculated, which is equal to sum of the value of sub-indicators $\left(\mathrm{S}_{\mathrm{k}}\right)$. The evaluation of the indicator "Organizational Chart" is expressed as; $\mathrm{S}_{1}$, evaluation of the indicator "Corporate Logo" is expressed as; $\mathrm{S}_{2}$ and so on. Each value of sub-indicator $\left(\mathrm{S}_{\mathrm{k}}\right)$ summed up, for the dimension Identity, actual value of Identity is calculated as 8 . Final value of the dimension Didentity is calculated as;

$$
\begin{gathered}
D_{\text {Identity }}=\frac{\text { Actual Value }}{\text { Possible Maximum Value }} 100 \\
D_{\text {Identity }}=\frac{S_{Q 1}+S_{Q 2}+S_{Q 3}+S_{Q 4}+S_{Q 5}+S_{Q 6}}{(c 1) k} \quad 100 \\
=\frac{2+1+2+0+2+1}{(31) 6} 100=66,67
\end{gathered}
$$

Although the highest value is 12 , actual value is 8 , which indicates a $\% 66,7$ success. Same calculations are carried for other dimensions for the firm $\mathrm{f}$. The DIdentity value evaluated above is the evaluation for the firm $\mathrm{f}$ in one dimension. Once we know there are 6 dimensions in total, overall evaluation $\left(\mathrm{T}_{\mathrm{f}}\right)$ is the average of DIdentity, $\mathrm{D}_{\text {Content, }} \mathrm{D}_{\text {Service, }}$, D Location, $\mathrm{D}_{\text {Management }}$ and DUsability.

To summarize, the value of a dimension $\left(\mathrm{D}_{\mathrm{n}}\right)$ is calculated according to the actual and maximum possible value of the dimension. Possible maximum value represents the possible highest value of a dimension can have; while actual value is the sum of the evaluations of sub-indicators $\left(\mathrm{S}_{\mathrm{k}}\right)$. Percentage of the actual value of the dimension within the highest value is calculated as;

$$
D_{n}=\frac{\sum_{k=1}^{k} S_{k}}{\left(\begin{array}{lll}
c & 1
\end{array}\right) \quad k} 100
$$

This formula $\left[(\mathrm{c}-1)^{*} \mathrm{k}\right]$ is the greatest value for a firm to have in a specific dimension, so the $\mathrm{D}_{\mathrm{n}}$ represents the achievement percentage of the firm with regard to the greatest value.

\section{Findings}

Although the study started with top thirty firms with the highest R\&D spending, two of the firms were excluded, one due to inaccessibility to the website. For the other one, firms is also the sub-company of another, so these firms use the same website for the reason of vast amount of common knowledge. Therefore, the final sample size is reduced to twenty eight firms. Through the analysis of these firms, the measurement scale is adapted related to the sample websites. Moreover, analysis is carried according to the modified scale, as indicated in below sections.

\section{Reconsideration of the Measurement Scale}

Dimensions offered by 2QCV2Q Model are modified in order to obtain samplespecialized sub-indicators for this research. Some sub-indicators such as "contact information", exist in every sample website. The indicators existing in all twenty eight firms which means there is no differentiation between firms, are not considered to be significant for the evaluation and are removed. On the other hand, some extra sub-indicators, such as "multiple domain", are considered significant and added to the model. Added indicators are considered to be significant and highly relevant for the sample websites. The removed sub-indicators are; 
"links", "News from new products / services, press releases", "reachability of website", "accessibility", "contact information", "FAQ"; where added sub-indicators are "multiple website domains" and "journal, periodical or press release".

Appendix 1 presents the adapted model and also summarizes the evaluation categorization of indicators. The categorization is not offered as a standard tool to evaluate the quality of websites, contrarily the categories are constructed according to the sample. Sample specific category construction is discussed in conclusion with pros and cons.

\section{Demographics of Firms}

Demographic factors emphasize the top firms in Turkey in terms of R\&D expenditure for 2014, the industry they are in, the number of personnel working in research and development and partnership condition. Besides being the most innovative firms as a common point, firms vary according to the sectors, cities and company structure. Table 2 summarizes the differences of the firms.

Table 2: Demographic Firm Characteristics

\begin{tabular}{|c|c|}
\hline Area & Distribution \\
\hline Provinces & $\begin{array}{l}\text { Istanbul: } 15(\% 53,6) \\
\text { Ankara: } 4(\% 14,3) \\
\text { Kocaeli } 3(\% 10,7) \\
\text { Eskişehir: } 2(\% 7,1) \\
\text { Izmir: } 1(\% 3,6) \\
\text { Bursa: } 1(\% 3,6) \\
\text { Adana: } 1(\% 3,6) \\
\text { Sakarya: } 1(\% 3,6)\end{array}$ \\
\hline Number of staff & $\begin{array}{l}\text { Average: } 9945 \text { employees } / 22 \text { firms (available) }=452 \\
\text { Max. - Min. numbers : } 2152-32\end{array}$ \\
\hline Customer Profile & $\begin{array}{l}\text { BtoB: } 15(\% 53,6) \\
\text { BtoC: } 13(\% 46,4)\end{array}$ \\
\hline $\begin{array}{l}\text { Structure of } \\
\text { Stakeholders }\end{array}$ & $\begin{array}{l}\text { Established with foundation cooperation: } 7(\% 0,25) \\
\text { Firms in connection with the conglomerate: } 10(\% 35,7) \\
\text { Firms publicly-traded: } 18(\% 64,3)\end{array}$ \\
\hline Industry & $\begin{array}{l}\text { Automotive: } 8(\% 28,5) \\
\text { Consumer electronics, home appliance, digital products: } 4(\% 14,2) \\
\text { Defense: } 4(\% 14,2) \\
\text { Telecommunication, Information and Communication Technologies: } 3 \\
(\% 10,7) \\
\text { Health: } 2(\% 7,1) \\
\text { Aviation and Space Industry: } 2(\% 7,1) \\
\text { Manufacturing of industrial nylon, polyester yarn, tire cord fabric, } \\
\text { single end cord: } 1(\% 3,5) \\
\text { Glass, glassware, glass packaging, chemicals: } 1(\% 3,5) \\
\text { Refining and Petroleum Products: } 1(\% 3,5) \\
\text { Software: } 1(\% 3,5) \\
\text { Paints: } 1(\% 3,5)\end{array}$ \\
\hline
\end{tabular}

\section{Identity}


Identity as a dimension is composed of six indicators as seen in Appendix 1, which are all categorized in three levels. The result for identity is presented in Table 3.

Table 3. Findings for the indicators of "Identity"

\begin{tabular}{|c|c|c|c|c|}
\hline Sub-Indicator & $\begin{array}{c}\text { Average of Sub- } \\
\text { indicator } \\
\text { Values }\end{array}$ & $\begin{array}{l}\text { Range of } \\
\text { category }\end{array}$ & $\begin{array}{l}\% \text { of each } \\
\text { category }\end{array}$ & $\begin{array}{l}\text { Standard deviation } \\
\text { between firms }\end{array}$ \\
\hline Organization chart & 0,54 & \multirow[t]{6}{*}{$0-2$} & $\begin{array}{l}0: \% 60,7 \\
1: \% 25,0 \\
2: \% 14,3\end{array}$ & 0,74 \\
\hline Corporation logo & 1,36 & & $\begin{array}{c}0: \% 3,6 \\
1: \% 57,1 \\
2: \% 39,3\end{array}$ & 0,56 \\
\hline $\begin{array}{l}\text { Vision / Mission } \\
\text { statement }\end{array}$ & 1,14 & & $\begin{array}{c}0: \% 39,3 \\
1: \% 7,4 \\
2: \% 53,6\end{array}$ & 0,97 \\
\hline Company history & 1,32 & & $\begin{array}{r}0: \% 3,6 \\
1: \% 60,7 \\
2: \% 35,7\end{array}$ & 0,54 \\
\hline Board of Directors & 0,82 & & $\begin{array}{l}0: \% 46,4 \\
1: \% 25,0 \\
2: \% 28,5\end{array}$ & 0,84 \\
\hline $\begin{array}{l}\text { Message from CEO, } \\
\text { Top Management }\end{array}$ & 0,39 & & $\begin{array}{l}0: \% 67,8 \\
1: \% 25,0 \\
2: \% 7,14\end{array}$ & 0,63 \\
\hline
\end{tabular}

As seen in Table 3, information about firm identity is not properly given in corporate websites of these firms. Amongst these firms, only one firm's website has information about all indicators. Besides, the highest deviation is seen in Vision and Mission statements where almost \%40 of the firms does not publish firm's mission or vision in corporate websites. Indicators of organizational chart and board of directors may be expected to be evaluated similarly, though as seen in Appendix 1, there is a significant difference in evaluation. Unlike the indicator "organizational chart", management committee is expressed as a schema in every sample, so the categorization differentiated for these two indicators.

\section{Content}

Table 4 represents seven indicators of "Content" dimension showing the average, range and percentage of categories and standard deviation.

Table 4: Findings for the indicators of "Content"

\begin{tabular}{|c|c|c|c|c|}
\hline Sub-Indicator & $\begin{array}{c}\text { Average of } \\
\text { Sub-indicator } \\
\text { values }\end{array}$ & $\begin{array}{c}\text { Range } \\
\text { of } \\
\text { category }\end{array}$ & $\begin{array}{c}\text { \% of each } \\
\text { category }\end{array}$ & $\begin{array}{c}\text { Standard } \\
\text { deviation } \\
\text { between firms }\end{array}$ \\
\hline Product information & 1,21 & $0-2$ & $0: \% 0$ & 0,42 \\
\hline
\end{tabular}




\begin{tabular}{|c|c|c|c|}
\hline & & $\begin{array}{l}1: \% 78,5 \\
2: \% 21,4\end{array}$ & \\
\hline $\begin{array}{l}\text { Innovation related } \\
\text { information }\end{array}$ & 1,11 & $\begin{array}{l}0: \% 17,9 \\
1: \% 53,6 \\
2: \% 28,6\end{array}$ & 0,68 \\
\hline Certificates & 1,07 & $\begin{array}{l}0: \% 28,6 \\
1: \% 35,7 \\
2: \% 35,7\end{array}$ & 0,81 \\
\hline $\begin{array}{l}\text { Information related with } \\
\text { stakeholders (customers, } \\
\text { suppliers etc.) }\end{array}$ & 0,89 & $\begin{array}{l}0: \% 32,1 \\
1: \% 46,4 \\
2: \% 21\end{array}$ & 0,74 \\
\hline $\begin{array}{l}\text { Issues related with } \\
\text { environment or } \\
\text { sustainability report }\end{array}$ & 0,54 & $\begin{array}{l}0: \% 57,1 \\
1: \% 32,1 \\
2: \% 10,7\end{array}$ & 0,69 \\
\hline $\begin{array}{l}\text { Issues related with social } \\
\text { responsibility }\end{array}$ & 1,43 & $\begin{array}{l}0: \% 10,7 \\
1: \% 35,7 \\
2: \% 53,6\end{array}$ & 0,69 \\
\hline $\begin{array}{l}\text { Financial } \\
\text { information/report }\end{array}$ & 1,46 & $\begin{array}{l}0: \% 17,8 \\
1: \% 17,8 \\
2: \% 64,3\end{array}$ & 0,79 \\
\hline
\end{tabular}

When the product information is considered, relation with the existence of multiple domains should be underlined. Two of the firms in group 2, use multiple domains and product details can be achievable in the subordinate domain. For instance, one-fifth of firm's product information exist in a separate website. However, product information is attainable with one click or exist in main page in the vast majority of firms. Innovation related information do not exist in $\% 17$ of firms. However, innovation information exist as a separate section in close to one-third of firms and exist within other sections in half of firms. In one-third of firms, a separate section related with stakeholder information does not exist. However, in close to half of firms, there is a section/information for one particular stakeholder and in one-fifth of firms, there is a section/information for more than one stakeholder. Regarding to financial reports that firms share on corporate websites, only five firms give no financial information. In addition, more than half of firms post financial information or annual reports on their websites and \% 18 share that kind of information as information society service via redirecting to another website.

\section{Service}

Table 5 emphasizes seven indicators of "Service" dimension showing the average, range and percentage of categories and standard deviation.

Table 5: Findings for the indicators of "Service"

\begin{tabular}{|l|c|c|c|c|}
\hline Sub-Indicator & $\begin{array}{c}\text { Average of Sub- } \\
\text { indicator values }\end{array}$ & $\begin{array}{c}\text { Range of } \\
\text { category }\end{array}$ & $\begin{array}{c}\text { \% of each } \\
\text { category }\end{array}$ & $\begin{array}{c}\text { Standard deviation } \\
\text { between firms }\end{array}$ \\
\hline Email & 0,86 & $0-2$ & $\begin{array}{c}0: \% 42,9 \\
1: \% 28,6\end{array}$ & 0,85 \\
\hline
\end{tabular}




\begin{tabular}{|c|c|c|c|}
\hline & & $2: \% 28,6$ & \\
\hline Contact form & 1,32 & $\begin{array}{l}0: \% 21,4 \\
1: \% 25,0 \\
2: \% 53,6\end{array}$ & 0,82 \\
\hline News/announcements & 1,00 & $\begin{array}{l}0: \% 17,9 \\
1: \% 64,3 \\
2: \% 17,9\end{array}$ & 0,61 \\
\hline Newsletter & 0,82 & $\begin{array}{l}0: \% 35,7 \\
1: \% 46,4 \\
2: \% 17,9\end{array}$ & 0,72 \\
\hline $\begin{array}{l}\text { Human resources } \\
\text { /employment opportunities }\end{array}$ & 1,57 & $\begin{array}{c}0: \% 7,1 \\
1: \% 28,6 \\
2: \% 64,3\end{array}$ & 0,63 \\
\hline Customer service/support & 0,89 & $\begin{array}{c}0: \% 14,3 \\
1: \% 82,1 \\
2: \% 3,6\end{array}$ & 0,42 \\
\hline Investor relations/support & 1,39 & $\begin{array}{l}0: \% 17,9 \\
1: \% 25,0 \\
2: \% 57,1\end{array}$ & 0,78 \\
\hline
\end{tabular}

As stated in Table 5, an e-mail address does not exist in almost half of websites whereas one mail address (generally customer service) exists in one-third of firm's websites and more than one e-mail address exists in one-third of firm's websites. It seems that most of the firms prefer contact forms on their websites. For the news and newsletter, in general, firms are likely to share news and announcements on their corporate websites and more than half of them have newsletter and publications. Human resources is another important indicator that vast majority of firms use corporate websites as a recruitment tool. Regarding to customer services, little attention is given to customer services or support on websites. However, majority of websites provides customer services such as products, services or after-sales services. On the other hand, firms place more emphasis on investor relations or support as more than half of firms have a particular section for investor relations.

\section{Location}

Table 6 mainly emphasizes eight indicators of "Location" dimension showing the average, range and percentage of categories and standard deviation.

Table 6: Findings for the indicators of "Location"

\begin{tabular}{|c|c|c|c|c|}
\hline Sub-Indicator & $\begin{array}{l}\text { Average of Sub- } \\
\text { indicator values }\end{array}$ & $\begin{array}{l}\text { Range of } \\
\text { category }\end{array}$ & $\%$ of each category & $\begin{array}{l}\text { Standard deviation } \\
\text { between firms }\end{array}$ \\
\hline LinkedIn & 0,68 & \multirow[t]{3}{*}{$0-1$} & $\begin{array}{l}0: \% 32,1 \\
1: \% 67,9\end{array}$ & 0,47 \\
\hline Facebook & 0,75 & & $\begin{array}{l}0: \% 25,0 \\
1: \% 75,0\end{array}$ & 0,44 \\
\hline Twitter & 0,71 & & $\begin{array}{l}0: \% 28,6 \\
1: \% 71,4\end{array}$ & 0,46 \\
\hline
\end{tabular}




\begin{tabular}{|c|c|c|c|}
\hline Blog & 0,11 & $\begin{array}{l}0: \% 89,3 \\
1: \% 10,7\end{array}$ & 0,31 \\
\hline Google plus & 0,43 & $\begin{array}{l}0: \% 57,1 \\
1: \% 42,9\end{array}$ & 0,50 \\
\hline YouTube & 0,71 & $\begin{array}{l}0: \% 28,6 \\
1: \% 71,4\end{array}$ & 0,46 \\
\hline Instagram & 0,39 & $\begin{array}{l}0: \% 60,7 \\
1: \% 39,3\end{array}$ & 0,49 \\
\hline $\begin{array}{l}\text { Journal, periodical } \\
\text { or press release }\end{array}$ & 0,78 & $\begin{array}{l}0: \% 21,4 \\
1: \% 78,6\end{array}$ & 0,42 \\
\hline
\end{tabular}

Highly preferred social platform is Facebook, besides video sharing via YouTube is also prevalent for most of the firm's corporate websites. Yet more, journal, periodical or press release is also highly preferred by the firms. On the other hand, vast majority of firms do not have a blog, they use other media tools. More than half of the firms have a LinkedIn account.

\section{Management}

Management is composed of four indicators; one of them is added by the authors. Although more information is needed to fully understand the quality of website management, since the information is gathered through websites only, the indicators are covering only a part of management process.

Table 7: Findings for the indicators of "Management"

\begin{tabular}{|c|c|c|c|c|}
\hline Sub-Indicator & $\begin{array}{l}\text { Average of Sub- } \\
\text { indicator values }\end{array}$ & $\begin{array}{l}\text { Range of } \\
\text { category }\end{array}$ & $\begin{array}{l}\% \text { of each } \\
\text { category }\end{array}$ & $\begin{array}{l}\text { Standard deviation } \\
\text { between firms }\end{array}$ \\
\hline $\begin{array}{l}\text { Information of site } \\
\text { update }\end{array}$ & 0,03 & \multirow[t]{4}{*}{$0-1$} & $\begin{array}{c}0: \% 96,4 \\
1: \% 3,6\end{array}$ & 0,19 \\
\hline $\begin{array}{l}\text { Live support - } \\
\text { online chat }\end{array}$ & 0,03 & & $\begin{array}{l}0: \% 96,4 \\
1: \% 3,6\end{array}$ & 0,19 \\
\hline $\begin{array}{l}\text { Multiple website } \\
\text { domains }\end{array}$ & 0,43 & & $\begin{array}{l}0: \% 57,1 \\
1: \% 42,9\end{array}$ & 0,50 \\
\hline Broken links & 0,78 & & $\begin{array}{c}0: \% 89,3 \\
1: \% 10,7\end{array}$ & 0,42 \\
\hline
\end{tabular}

As seen in Table 7, a clear differentiation can be recognized in live support, where only one firm's website offers this property. For the indicator of "broken links", since the term is negative unlike any other indicators in the model, the evaluation is different as seen in Appendix 1.

Besides, multiple website domains are mostly observed in international and sub-firms, in some cases the product details are in another domain. For only one firm, the existence of second domain is not related to being a sub-company, but as we guess, the website is on the way of changing and some data is still accessible from the previous website domain.

When broken links are considered, during the website evaluation even if there is only one broken link (for instance "news" is announced in the ribbon menu, though not achievable when clicked), than the firm is considered in the category of ' 1 '. 


\section{Usability}

Table 8 stresses four indicators of "Usability" dimension showing the average, range and percentage of categories and standard deviation.

Table 8: Findings for the indicators of "Usability"

\begin{tabular}{|c|c|c|c|c|}
\hline Sub-Indicator & $\begin{array}{l}\text { Average of Sub- } \\
\text { indicator values }\end{array}$ & $\begin{array}{l}\text { Range of } \\
\text { category }\end{array}$ & $\begin{array}{l}\% \text { of each } \\
\text { category }\end{array}$ & $\begin{array}{c}\text { Standard deviation } \\
\text { between firms }\end{array}$ \\
\hline $\begin{array}{l}\text { Site map/table of } \\
\text { contents }\end{array}$ & 0,82 & \multirow[t]{4}{*}{$0-2$} & $\begin{array}{c}0: \% 57,1 \\
1: \% 3,6 \\
2: \% 39,3\end{array}$ & 0,98 \\
\hline $\begin{array}{l}\text { People with } \\
\text { disabilities }\end{array}$ & 0,11 & & $\begin{array}{c}0: \% 92,9 \\
1: \% 3,6 \\
2: \% 3,6\end{array}$ & 0,42 \\
\hline Search engine & 0,61 & & $\begin{array}{c}0: \% 17,9 \\
1: \% 3,6 \\
2: \% 78,6\end{array}$ & 0,78 \\
\hline Language options & 1,00 & & $\begin{array}{l}0: \% 17,9 \\
1: \% 64,3 \\
2: \% 17,9\end{array}$ & 0,61 \\
\hline
\end{tabular}

Site map or table of contents do not exist in more than half of firms. They are attainable with one click in a few firms and they exist in main page in \%39 of firms. People with disabilities are underestimated in general. Only one of all firms has a particular link, and one provides special services for people with disabilities. Information related with people with disabilities do not exist in vast majority of firms. In general, search engine exists in majority of firms. Regarding to language options, more than half of firms offer bilingual web pages as Turkish and English; and foreign language options more than one exist in $\% 17$ of firms in their websites.

\section{Inter-dimensional Evaluation}

In this section, above mentioned findings are examined in accordance with the interdimensional perspective. Considering the demographics, the province that the firm is located is not evaluated in these sections, due to the low frequency in Izmir, Bursa, Adana and Sakarya, which would reveal the name of the firm. Instead of these issues, serving $\mathrm{BtoB}$ or $\mathrm{BtoC}$, and being publicly-traded company are considered as seen in Table 9.

Table 9: The value (\%) of dimensions according to demographic diffraction.

\begin{tabular}{|c|c|c|c|c|}
\hline$*$ & \multicolumn{2}{|c|}{ BtoB } & \multicolumn{2}{c|}{ BtoC } \\
\hline Dimension & Not Publicly-Traded & Publicly-Traded & Not Publicly-Traded & Publicly-Traded \\
\hline Identity & 40,5 & 60,4 & 33,3 & 44,4 \\
\hline Content & 35,7 & 67,9 & 44,6 & 63,5 \\
\hline Service & 48,0 & 67,9 & 44,6 & 57,1 \\
\hline Location & 41,1 & 65,6 & 56,3 & 62,5 \\
\hline Management & 14,3 & 20,3 & 6,3 & 19,4 \\
\hline
\end{tabular}




\begin{tabular}{|c|c|c|c|c|}
\hline Usability & 51,8 & 42,2 & 31,3 & 45,8 \\
\hline
\end{tabular}

*The number of firms in BtoB is: 7 (not publicly-traded firms), 8 (publicly-traded firms) where BtoC is; 4 (not publicly-traded firms) and 9 (publicly-traded firms).

As seen in Table 9, being a publicly-traded firm effect the website evaluation results positively in overall and in every dimension, except Usability in BtoB. This may be related to the concern of publicly-traded firms to be posed like a preferable investment.

Ranking 28 firms evaluated within this study according to the overall website quality. Management is considered to be the lowest competency for almost every firm, which is questioned in conclusion.

It is essential to understand the highly graded firm websites and the first five firms in overall website quality ranking are observed. Firms are named as A to E where A is the firm having the highest degree from the overall website quality value and not necessarily related to the innovative firm ranks of Turkishtime. Evaluations are shown as a radar chart. As seen in Figure 1, the lowest value of the first five firms is about the management of websites, relatedly the deviation in this dimension is zero. On the other hand; identity, content, service and location are the dimensions that the websites are well developed in. There is a clear differentiation of firm $\mathrm{D}$, which is relatively well constructed in content, usability and identity.

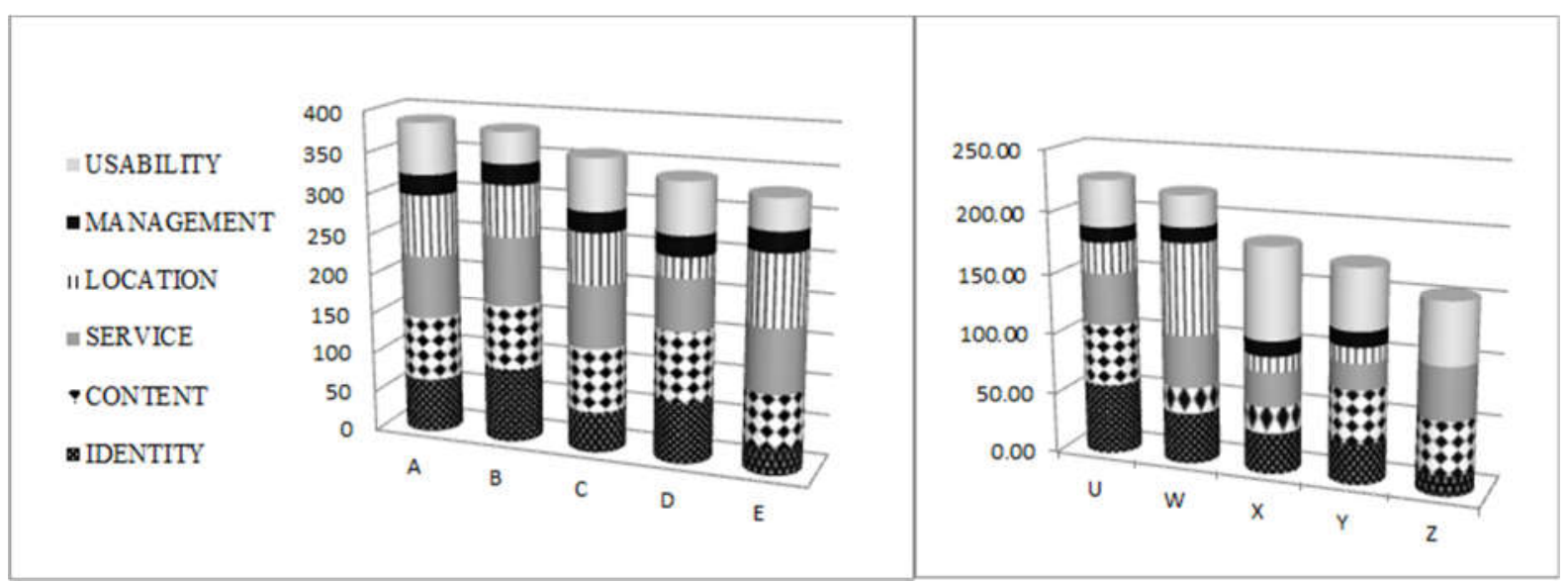

Figure 1: First (A-E) and last (U-Z) five firm's value in dimensions, in the evaluation of website

In order to compare the evaluations for the lowest five firms, similarly firms are named as U-Z. The radar chart is also seen in Figure 1. As seen in Figure 3, firms having the lowest value from the overall evaluation of the website $\left(\mathrm{D}_{\mathrm{f}}\right)$ show great diversification unlike the first five firms. Unexpectedly, the firm "W" is included in all channels to communicate with the customers as seen in "Location", clearly having the highest degree (75) amongst firms U-Z. Also, the firm " $X$ " has the greatest value (75) in Usability dimension amongst the 28 firms.

For an overall evaluation, there is no direct relationship between R\&D spending and website quality; though there are several issues to be discussed. Management is recognized to be the weakest dimension for almost every firm. Considering the overall website scores (see Figure 2), the highest website score belongs to the highest R\&D spending firm. Apart from that, there is no direct relationship between the variables. Some firms are also recognized to facilitate websites more than others. 


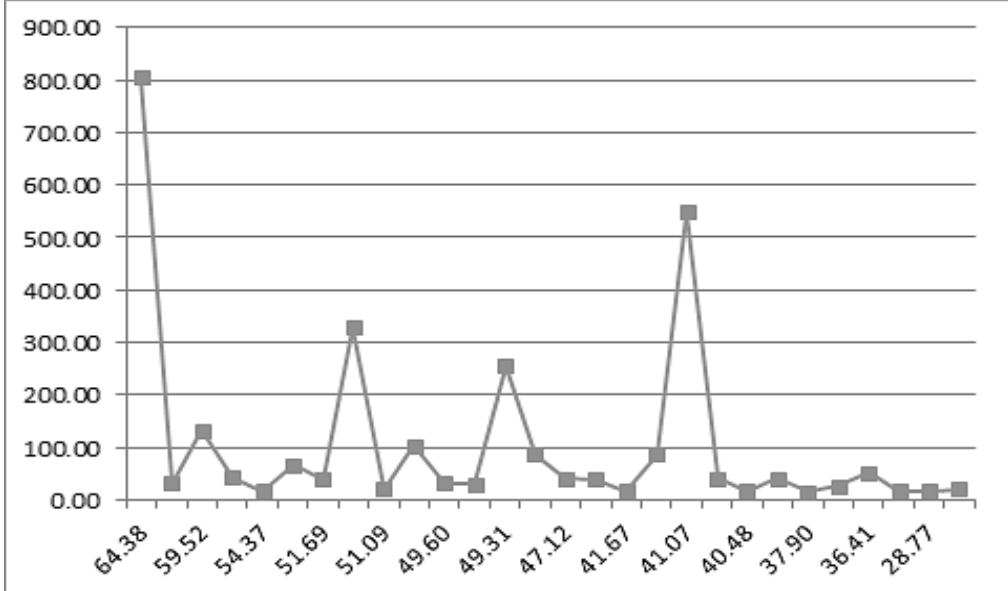

Figure 2: R\&D Spending of the firms ranked according to overall score of website evaluation

\section{Evaluation of Findings}

The aim of the paper is to understand the innovation oriented positioning of high R\&D spending firms. Corporate websites of the firms are analyzed via 2QCV2Q Model. The Model is also composed of six dimensions, all of which have different quantity of indicators. Since 2QCV2Q Model provides a general framework for evaluating web sites, sub-indicators of the dimensions are determined related to the sample web sites.

According to the demographics, firms mostly operate in Istanbul and the top three industries are "Automotive", "Consumer electronics, home appliance, digital products" and "Defense". Firms in defense sector are recognized to be the supplier of government military forces military forces, mostly related to a foundation, where $\% 28$ of firms is related to foundations. On the other hand, this study is not present in any sector-based differentiation due to the low frequencies.

Observing the first dimension Identity, it is about the firm's expression of core values (mission and vision), top management, organization of employees etc. Even if identity is expected to be crucial information in the website, results indicate high deviation especially for the indicator "message from CEO". In this case, one should question the relationship of mission and vision, or the message of CEO for several stakeholders, with the positioning strategy of firm through its identity.

Content as being another dimension offered by 2QCV2Q is not directly related to the detailed analysis of whole website content, but mostly is based on the existence of a prespecified information such as product information. Firms have different ways of presenting their product through their corporate websites. Mainly, product information is attainable with one click or exist in main page in \%78 of firms. Surprisingly, innovation related information do not exist in $\% 18$ of these firms. However, information about innovation exist as a separate section in $\% 28$ of firms and exist within other sections in more than half of the firms. Firms present their certificates in various ways. In $\% 28$ of firms, certificates are either not mentioned or firm does not have a certificate. Specifically, in \%35 of firms, certificates are mentioned in websites but are not accessible. Firms also deal with their various stakeholders in several ways. However, in close to half of firms, there is a section for one particular stakeholder and in onefifth of firms there is a section/information for more than one stakeholder. Matters related with social responsibility are also emphasized in vast majority of the firms.

Websites offering various services are analyzed through service dimension. Indicators of service can be discussed considering studies about website service quality related to ecommerce (Ahmad et al., 2016), browsing time (Postelnicu et al., 2016) and other several 
studies (Chuang et al., 2016). Service is a dimension which can be measured through widely different perspectives. According to the model used in this study, service is considered through customers, job seekers and investors' perspectives, besides a general evaluation through e-mail, newsletter etc. Results indicate that lowest standard deviation is recognized in customer service support, where the average of the firms is 0,89. Besides, the indicator of human resources/employment opportunities also shows the highest average of 1,57.

Firms highly associated with internet are expected to be using social media and other tools, as the dimension "location" investigates. According to the results, highly preferred location is "journal, periodical, press release" indicator, the reason of it's highly preference may be related to the fact that this indicator is composed of similar locations as a group. Besides, Facebook, Youtube and Twitter are the most facilitated social media tools. At this point, it should be indicated that the results are based on the shared information in the websites, which means that a firm having a twitter account is counted as ' 1 ', only if it is indicated in the firm's official website. Plus, more than half of the firms have a LinkedIn account. In general, it is assumed that the usage of social media will further increase with different tools in the near future.

Management of the website is another issue to be considered in website evaluation. In the modified model, management dimension holds the lowest number of indicators amongst other dimensions. Current indicators of management also hold the lowest standard deviation. Kamanlioglu and Emiroglu (2009) also indicate low deviation in management dimension (they express this dimension as maintenance), though management is also recognized to be the most constructed dimension for the websites.

Besides, as seen in Appendix 1, the indicators of live support and information about site update, a few firm websites are considered to be sufficiently constructed. Serving with multiple website domains is also another issue to be discussed, since mostly foreign originated firms tend to have the same details in a second website domain. Though one of the firms have two domains where these websites have different designs and complementary knowledge.

Dimension "usability", is composed of four indicators such as management, but the standard deviation of indicators are respectively high. Website facilities for people with disabilities are low since only one firm is evaluated to have facilities and it has only live support and needs to be improved.

A specific differentiation is recognized amongst publicly traded and not publicly traded firms through the evaluation of websites. Publicly traded firms are recognized to have higher score for almost every dimension; this result may be related to the firm's concern to be more attractive for investors. There are several studies observing publicly traded firms according to financial issues (Gentry, 1994; Gilligan and Skrepnek, 2013) business ethics (Gunthorpe, 1997), firm management (Millstein and MacAvoy, 1998). Though, a study observing the differences of publicly traded firms' website is not recognized to be carried, so the results could not be compared to literature. In a nutshell, the website evaluation of the firms with the highest R\&D expenditure in Turkey-centric papers is practically non-existent which indicates the significant contribution of this paper.

\section{Conclusion}

The main purpose of this research is to investigate the positioning of firms through corporate websites, where corporate website of high R\&D spending firms in Turkey, listed in Turkishtime is evaluated. There are three research questions investigating (1) characteristics of the firm websites, (2) similarities and differences of the websites and (3) evaluation of corporate 
websites through positioning strategy. First two questions are analyzed through the dimensions and indicators offered by 2QCV2Q Model, via comparison graphs. Besides, the evaluation process is modified in order to improve the wealth of data, obtain sample specific results and offer a clearly indicated evaluation for practitioners and academicians. For the third question, overall results indicate no direct relationship between model scores and R\&D spending. Though, results indicate weak interest in management dimension, regardless of the amount of R\&D spending. Besides, some dimensions such as Location, is recognized to be strongly indicated due to some firm specific cases.

Although, the list of highest R\&D spending firms published by Turkishtime can be achievable in order to keep the firm name hidden, results are carefully presented and some details are not indicated purposely. Due to the low frequencies, firms are not indicated through sectors in order not to decipher the firms. Considering the various sectors of most innovative firms in Turkey, similarities and differences in construction of websites are also analyzed. In addition, for the innovativeness of the firms, this research focused only on the R\&D expenditures of firms although literature provides many other antecedents for innovation orientation.

The most critical part in this research is to adapt the measurement according to the sample. As a result of the pre-test, some indicators take place in every firm's website, thus removed from the scale because they would be statistically insignificant. Kamanlioglu and Emiroglu (2009) also recognized \%64 of indicators to be insignificant related to the same issue. Therefore, these indicators are decided to be out of evaluation through a sample-specific perspective. On the other hand, extracted indicators may be used for future studies and some other indicators can be added based on the purpose of research also.

For this study, relatively long time is allocated for the consideration of the analysis related to time constraints and difficulty in reaching specific data. Due to different categorization of the indicators, dimensions are re-evaluated for a couple of times in order to obtain same number of categories (at least) within a dimension. Though, the whole scale is not considered to be appropriate for a three level categorization (evaluations as 0,1 or 2). After the evaluation of firms and setting the proper categorization, the second challenging issue has come into prominence; the way of evaluation. Since the data is categorical and sample size is relatively low, a standard method such as regression, confirmatory component analysis or cluster analysis is not logical to be applied. A clear statement of evaluation methodology may inspire practitioners to apply the scale, where the indicators may be reconsidered related to the quality and quantity of sample.

The relativeness of indicators to the dimension is another issue that can be discussed for further research. For instance, a new dimension related to innovation can also be included in the model, or indicators may be shifted to another existing dimension. For example, innovative capacity may be a new dimension for innovative firm website evaluation. Also, the way of measurement methodology may be reconsidered, such that researchers may get in touch with the firm staff responsible from the website management for the dimension of "management". For future studies, other firms or firms in specific industries by categorization and different methodology can be analyzed as well. Besides these top 28 innovative firms, other firms listed in Turkishtime, considering other perspectives, not just the R\&D expenditures, can also be evaluated with different measurement factors or indicators. Besides, this study can be widened by evaluating through SERVQUAL (Parasuraman et al., 1985) which is widely used for measuring service quality (Chuang et al., 2016). Since this study only focuses on the actual service quality, the expected service quality through customer perspective can be measured. 
As a fact, here are two main gaps intended to be filled with this study. One is to put in practice of the 2QCV2Q model for the innovation oriented positioning firms and second is to see the relationship between positioning and corporate website comprehending various dimensions. This study stands as a first step to develop an innovation-related website evaluation, reminding the fact that no strict tool is offered to evaluate the firm websites. This research sheds a light and rises more research questions in this field of study for both researchers and practitioners.

\section{References}

Ahmad, A., Rahman, O., and Khan, M. N. (2016). Consumer's perception of website service quality: An empirical study. Journal of Internet Commerce 15(2), 125-141.

Al-Mouh, N., and Al-Khalifa, H. S. (2016). Enhancing web accessibility by implementing context aware proxy. International Journal of Web Information Systems 12(2), 201-214. doi:10.1108/IJWIS-11-2015-0037.

Argyriou, E, Kitchen, P. J., and Melewar, T. C. (2006). The relationship between corporate websites and brand equity: A conceptual framework and research agenda. International Journal of Market Research 48(5), 575-599. ISSN 1470-7853.

Bai, B., Law, R., and Wen, I. (2008). The impact of website quality on customer satisfaction and purchase intentions: Evidence from Chinese online visitors. International Journal of Hospitality Management 27(3), 391-402.

Bulíček, J., and Drdla, P. (2015). Quality of urban public transport websites according to extent of provided information. Transport 30(2), 202-216. doi:10.3846/16484142.2015.1048721.

Bulut, C., Mutlu, E. E., and Nazli, M. (2013). Innovation and entrepreneurship assessment initiatives: A critical view. Proceedings for the 8th European Conference on Innovation and Entrepreneurship: ECIE 2013. Academic Conferences Limited.

Cengiz, G., and Akkuş, Ç. (2015). Erzurum ili turizm işletmeleri keb Kullanımı ve web sitelerinin değerlendirilmesi. Atatürk Üniversitesi İktisadi Ve İdari Bilimler Dergisi, 29(3), 441. Gentry, W. M. (1994). Taxes, financial decisions and organizational form: evidence from publicly traded partnerships. Journal of Public Economics 53(2), 223-244.

Chen, X., Huang, Q., and Davison, R. M. (2017). The role of website quality and social capital in building buyers' loyalty. International Journal of Information Management 37(1), 15631574. doi:10.1016/j.ijinfomgt.2016.07.005.

Chiu, W., and Won, D. (2016). Relationship between sport website quality and consumption intentions application of a bifactor model. Psychological Reports 118(1), 90106. doi:10.1177/0033294115625269.

Chuang, H. M., Chen, Y. S., Lin, C. Y., and Yu, P. C. (2016). Featuring the e-service quality of online website from a varied perspective. Human-centric Computing and Information Sciences 6(6), 1-28. doi:10.1186/s13673-016-0058-1.

Chung, T., and Law, R. (2003). Developing a performance indicator for hotel websites. International Journal of Hospitality Management 22(1), 119-125. doi:10.1016/S02784319(02)00076-2.

Cooper, R. G. (1984). The performance impact of product innovation strategies. European Journal of Marketing 18(5), 5-54. doi:10.1108/EUM0000000004787.

Coy, C. (2003). Media relations and the Internet: how Fortune 500 company web sites assist journalists in news gathering. Public Relations Review 29(1), 29-41. doi:10.1016/S03638111(02)00196-0.

Ecer, F. (2014). A hybrid banking websites quality evaluation model using AHP and COPRASG: a Turkey case. Technological And Economic Development Of Economy 20(4), 758-782. doi:10.3846/20294913.2014.915596. 
Edelweis, R., Motz, R., and Diaz, A. (2011). Modelling a web site quality $\square$ based recommendation system. International Journal of Web Information Systems 7(4), 396-420. doi:10.1108/17440081111187574.

Favre-Bonte, V., and Tran, S. (2015). The contribution of the internet to the strategic positioning of small businesses in the tourism industry. International Journal of Entrepreneurship and Small Business 25(3). doi:10.1504/IJESB.2015.069698.

Faizan, A. (2016). Hotel website quality, perceived flow, customer satisfaction and purchase intention. Journal of Hospitality and Tourism Technology 7(2), 213-228. doi:10.1108/JHTT02-2016-0010.

Gilligan, M. A., and Skrepnek, H. G. (2013). Original Research: An analysis of security price risk and return among publicly traded pharmacy corporations. Research In Social And Administrative Pharmacy 9(6), 828-840. doi:10.1016/j.sapharm.2012.10.001.

Gonzalez, E. M., Quesada, G., Davis, J., and Mora-Monge, A. C. (2015). Application of quality management tools in the evaluation of websites: The case of sports organizations. Quality Management Journal 22(1), 30-46.

Gunthorpe, L. D. (1997). Business ethics: A quantitative analysis of the impact of unethical behavior by publicly traded corporations. Journal of Business Ethics 16(5), 537-543. doi:10.1023/A:1017985519237.

Huang, Z., and Cappel, J. J. (2012). A comparative study of web site usability practices of Fortune 500 versus INC. 500 companies. Information Systems Management 29(2), 112-122. doi:10.1080/10580530.2012.661633.

Jain, K. R., and Rangnekar, S. (2015). Measuring website quality of the Indian Railways. International Journal Of Entrepreneurial Knowledge 3(1), 57-64. doi:10.1515/ijek-2015-0011. Johnson, L. K., and Misic, M. M. (1999). Benchmarking: a tool for web site evaluation and improvement. Internet Research 9(5), 383-392.

Jones, S. (2015). A re-examination of Fortune 500 homepage design practices. IEEE Transactions On Professional Communication 58(1), 20-44. doi:10.1109/TPC.2015.2420371.

Jones, S., and DeGrow, D. (2011). Fortune 500 homepages: design trends. IEEE Transactions On Professional Communication, 1, 12-18. doi: 10.1109/TPC.2010.2044621.

Kamanlioglu, E., and Emiroglu, D. İ. (2009). Qualitative evaluation of web sites of firms in Turkish fishery sector. Ege Universitesi Su Urunleri Dergisi 26(1), 65-72.

Kang, D., Jang, W. and Park, Y. (2016). Evaluation of e-commerce websites using fuzzy hierarchical TOPSIS based on ES-QUAL. Applied Soft Computing 42, 53-65. doi:10.1016/j.asoc.2016.01.017.

Kim, D., Nam, Y., and Kang, S. (2010a). An analysis of corporate environmental responsibility on the global corporate web sites and their dialogic principles. Public Relations Review 36(3), 285-288. doi:10.1016/j.pubrev.2010.04.006.

Kim, S., Park, J. H., and Wertz, E. K. (2010b). Expectation gaps between stakeholders and web-based corporate public relations efforts: Focusing on Fortune 500 corporate web sites. Public Relations Review 36(3), 215-221. doi:10.1016/j.pubrev.2010.04.001.

Kim, S., and Stoel, L. (2014). Apparel retailers: website quality dimensions and satisfaction. Journal of Retailing and Consumer Services 11(2), 109-117. doi:10.1016/S09696989(03)00010-9.

Kline, S. F., Morrison, A. M., and St John, A. (2004). Exploring bed \& breakfast websites: A balanced scorecard approach. Journal of Travel \& Tourism Marketing 17(2-3), 253-267. doi:10.1300IJ073v17n02-19.

Kunz, M. B., and Ratliff, J. M. (2014). The state of sustainability of online reporting information of Fortune 500 corporations. International Journal of Business Research and Information Technology 1(1), 92-113. 
Kwon, Y. D., and Jeong, Seung R. (2015). A content analysis for website usefulness evaluation: Utilizing text mining technique. Journal Of Korean Society For Internet Information 16(4), 7181. doi:10.7472/jksii.2015.16.4.71.

Law, R., Shanshan Q., and Buhalis, D. (2010). Progress in tourism management: A review of website evaluation in tourism research. Tourism Management 31(3), 297-313. doi:10.1016/j.tourman.2009.11.007

Lee, I. (2005). The Evolution of e-recruiting: A content analysis of Fortune 100 career web sites. Journal Of Electronic Commerce In Organizations 3(3), 57.

Lee, Y., and Kozar, A. K. (2006). Investigating the effect of website quality on e-business success: An analytic hierarchy process approach. Decision Support Systems 42(3), 1383-1401. Leite, P., Gonçalves, J., Teixeira, P., and Rocha, A. (2014). Towards a model for the measurement of data quality in websites. New Review Of Hypermedia And Multimedia 20(4), 301-316. doi:10.1080/13614568.2014.968638

Liu, C., Arnett, P. K., Capella, M. L., and Beatty, C. R. (1997). Web sites of the Fortune 500 companies: Facing customers through home pages. Information And Management 31(6), $335-$ 345. doi:10.1016/S0378-7206(97)00001-3.

Liu, C., and Arnett, K. P. (2002). An examination of privacy policies in Fortune $500 \mathrm{Web}$ sites. American Journal of Business 17(1), 13-22. doi:10.1108/19355181200200001.

Liu, C., Arnett, K. P., and Litecky, C. (2000). Design quality of websites for electronic commerce: Fortune 1000 webmasters' evaluations. Electronic Markets 10(2), 120-129.

Loiacono, E. T., Romano Jr., N. C., and McCoy, S. (2009). The state of corporate website accessibility. Communications of the ACM 52(9), 128-132. doi:10.1145/1562164.1562197.

Mich, L., and Franch, M. (2000). 2QCV2Q: A Model for Web Site Analysis and Evaluation. Proc. Information Resources Management Association Int'l Conf. (IRMA '00), Idea Group Publishing: 586-589.

Millstein, I., and MacAvoy, P. (1998). The active board of directors and performance of the large publicly traded corporation. Columbia Law Review 98(5), 1283-1322. doi:10.1111/j.1745-6622.1999.tb00510.x.

Mohammed, I., Basak, D. G., Schuckert, M., and Law, R. (2016). An empirical investigation of corporate identity communication on Hong Kong hotels' websites. Journal Of Hospitality Marketing and Management 25(6), 676-705. doi:10.1080/19368623.2016.1096875.

Murphy, J., Forrest, J. E., Wotring, E. C., and Brymer, A. R. (1996). Hotel management and marketing on the Internet: An analysis of sites and features. The Cornell Hotel and Restaurant Administration Quarterly 37(3), 70-82.

Obal, M., and Kunz, W. (2013). Trust development in e-services: a cohort analysis of Millennials and Baby Boomers. Journal of Service Management 24(1), 45-63. doi:10.1108/09564231311304189.

Parasuraman, A., Zeithaml, V. A., and Berry, L. L. (1985). A conceptual model of service quality and its implications for future research. Journal of Marketing, 41-50. doi:10.2307/1251430.

Perry, M., and Bodkin, C. D. (2002). Fortune 500 manufacturer web sites: Innovative marketing strategies or cyberbrochures? Industrial Marketing Management 31(2), 133-144. doi:10.1016/S0019-8501(01)00187-0.

Pollach, I. (2011). The readership of corporate websites: A cross-cultural study. The Journal of Business Communication 48(1), 27-53. doi:10.1177/0021943610385657.

Postelnicu, Z., Raviv, T. and Ben $\square$ Gal, I. (2016). Improving websites' quality of service by shortening their browsing expected path length. Quality and Reliability Engineering International 32(6), 2017-2031. doi:10.1002/qre.2030. 
Raj, S., Sharma, V. L., Singh, A. J., and Goel, S. (2016). Evaluation of quality and readability of health information websites identified through India's major search engines. Advances in Preventive Medicine 2016: 1-6. doi:10.1155/2016/4815285.

Romano Jr., N. C. (2002). Customer relationship management for the web-access challenged: inaccessibility of Fortune 250 business web sites. International Journal of Electronic Commerce 7(2), 81-117.

Simeon, R. (1999). Evaluating domestic and international web-site strategies. Internet Research 9(4), 297-308. doi:10.1108/10662249910286842.

Smith, K. T., and Alexander, J. J. (2013). Which CSR-related headings do Fortune 500 companies use on their websites? Business Communication Quarterly 76(2), 155-171. doi:10.1177/1080569912471185.

Sullivan, J. (1999). What are the functions of corporate home pages? Journal of World Business 34(2), 193-210.

Sun, P., David A. C., and Rich H. (2015). Chinese customers' evaluation of travel website quality: A decision-tree Analysis. Journal of Hospitality Marketing \& Management 25(4), 47697. doi:10.1080/19368623.2015.1037977.

Tang, L., Christine C. G., and Bijie B. (2015). Corporate social responsibility communication through corporate websites: A comparison of leading corporations in the United States and China. International Journal of Business Communication 52(2), 205-227. doi:10.1177/2329488414525443.

Turkishtime (2015). Ar-Ge 250, retrieved from http://www.timakademi2023.org/backup/wpcontent/uploads/2013/07/ARGE-250-SON.pdf on 08 July 2016.

Usta, R. (2007). Türkiye'deki en büyük 100 sanayi işletmesinin web sitelerinin pazarlama iletişimi yönünden incelenmesi. Atatürk Üniversitesi İktisadi Ve İdari Bilimler Dergisi 21(2), 243-260.

Wells, J. D., Valacich, J. S., and Hess, T. J. (2011). What signal are you sending? How website quality influences perceptions of product quality and purchase intentions. MIS quarterly, 373396.

Williamson, O. I., King, E. J., Lepak, P. D., and Sarma, A. (2010). Firm reputation, recruitment web sites, and attracting applicants. Human Resource Management 49(4), 669-687.

Young, J., and Foot, K. (2005). Corporate E-cruiting: The construction of work in fortune 500 recruiting Web sites. Journal Of Computer-Mediated Communication 11(1), 44-71. doi:10.1111/j.1083-6101.2006.tb00303.x.

Zhao, J. J., Allen D. T., and Melody W. A. (2006). User-interface design characteristics of Fortune 500 B2C e-commerce sites and industry differences. Delta Pi Epsilon Journal 48(1), 43-55.

ISSN:0011-8052. 


\section{Appendix 1}

\begin{tabular}{|c|c|c|}
\hline Dimension & Indicator & Evaluation/Categorization \\
\hline \multirow[t]{6}{*}{ Identity } & Organizational Chart & $\begin{array}{l}\text { Not exist (0) } \\
\text { Exist as a list (1) } \\
\text { Exist as schema (2) }\end{array}$ \\
\hline & Corporation Logo & $\begin{array}{l}\text { Not proper colors, firm name is not } \\
\text { characteristic and logo does not exist }(0) \\
\text { Not proper colors or firm name is not } \\
\text { characteristic or logo does not exist }(1) \\
\text { Proper colors, logo exist and firm name is } \\
\text { characteristic (2) }\end{array}$ \\
\hline & Vision/Mission Statement & $\begin{array}{l}\text { Not exist }(0) \\
\text { Exist only one of them }(1) \\
\text { Exist together }(2)\end{array}$ \\
\hline & Company History & $\begin{array}{l}\text { Not exist (0) } \\
\text { Exist as text (1) } \\
\text { Exist as dynamic schema (2) }\end{array}$ \\
\hline & Message From Top Management & $\begin{array}{l}\text { Not exist }(0) \\
\text { Exist for a single manager (1) } \\
\text { Exist for more than one manager (2) }\end{array}$ \\
\hline & Management Committee & $\begin{array}{l}\text { Not exist (0) } \\
\text { Exist as schema (1) } \\
\text { Exist with the cv of managers (2) }\end{array}$ \\
\hline \multirow[t]{6}{*}{ Content } & Product Information & $\begin{array}{l}\text { Not exist }(0) \\
\text { Attainable with one click or in main page } \\
\text { (1) } \\
\text { Exist in separate web site (2) }\end{array}$ \\
\hline & Innovation Related Information & $\begin{array}{l}\text { Not exist }(0) \\
\text { Exist within other sections }(1) \\
\text { Exist as a separate section }(2)\end{array}$ \\
\hline & Certificates & $\begin{array}{l}\text { Not exist (0) } \\
\text { Exist but documents are not attainable (1) } \\
\text { Exist and documents are attainable (2) }\end{array}$ \\
\hline & $\begin{array}{l}\text { Information Related with Stakeholder } \\
\text { (customers, suppliers, investors etc.) }\end{array}$ & $\begin{array}{l}\text { A separate section do not exist }(0) \\
\text { Exist as a separate section for one } \\
\text { stakeholder (1) } \\
\text { Exist as a separate section for more than } \\
\text { one stakeholder (2) }\end{array}$ \\
\hline & Issues Related to Social Responsibility & $\begin{array}{l}\text { Not exist }(0) \\
\text { No report exist but topics mentioned in } \\
\text { site (1) } \\
\text { Exists separate reports for each, or at } \\
\text { least for one of them (2) }\end{array}$ \\
\hline & $\begin{array}{l}\text { Issues Related to Environment, Sustainability } \\
\text { Report }\end{array}$ & $\begin{array}{l}\text { Not exist }(0) \\
\text { Not exist as a separate section (1) } \\
\text { Exist as a separate section (2) }\end{array}$ \\
\hline
\end{tabular}




\begin{tabular}{|c|c|c|}
\hline & Financial Information/Report & $\begin{array}{l}\text { Not exist }(0) \\
\text { Exist as information society service (1) } \\
\text { Exist under a particular section on } \\
\text { corporate website (2) }\end{array}$ \\
\hline \multirow[t]{7}{*}{ Service } & Email & $\begin{array}{l}\text { Not exist (0) } \\
\text { Only one mail address exist (1) } \\
\text { (customer service in general) } \\
\text { Exist for more than one mail address (2) }\end{array}$ \\
\hline & Contact Form & $\begin{array}{l}\text { Not exist (0) } \\
\text { Exist but do not work (1) } \\
\text { Exist and active (2) }\end{array}$ \\
\hline & News/Announcements & $\begin{array}{l}\text { Not exist }(0) \\
\text { Only one exists }(1) \\
\text { Both news/announcement exist } \\
\text { separately }(2)\end{array}$ \\
\hline & Newsletter & $\begin{array}{l}\text { Not exist }(0) \\
\text { Exist but limited to information sharing } \\
\text { (1) } \\
\text { Exist and available as e-newsletter } \\
\text { or publications (2) }\end{array}$ \\
\hline & Human Resource/Employment Opportunity & $\begin{array}{l}\text { Not Exist (0) } \\
\text { Applications made by an external site (1) } \\
\text { Website accepts applications through its } \\
\text { system, a specific database/form for job } \\
\text { applications (2) }\end{array}$ \\
\hline & Customer Service/Support & $\begin{array}{l}\text { Not exist (0) } \\
\text { Not exist as a separate section (generally } \\
\text { services, products, service after sales, } \\
\text { price) (1) } \\
\text { Exist as a separate section (2) }\end{array}$ \\
\hline & Investor Relations/Support & $\begin{array}{l}\text { Not exist (0) } \\
\text { Not exist as a separate section (1) (some } \\
\text { financial information and reports for } \\
\text { investors) } \\
\text { Exist as a separate section (2) }\end{array}$ \\
\hline \multirow[t]{8}{*}{ Location } & Linkedin & \multirow{8}{*}{$\begin{array}{l}\text { Not exist (0) } \\
\text { Exist (1) }\end{array}$} \\
\hline & Facebook & \\
\hline & Twitter & \\
\hline & Blog & \\
\hline & Google Plus & \\
\hline & Youtube & \\
\hline & Instagram & \\
\hline & Journal, Periodical or Press Release & \\
\hline Management & Information About Date of Website Update & Not exist (0) \\
\hline
\end{tabular}




\begin{tabular}{|l|l|l|}
\hline \multirow{5}{*}{ Live Support/Online Chat } & Exist (1) \\
\cline { 2 - 3 } & Multiple Website Domains & $\begin{array}{l}\text { Not exist (0) } \\
\text { Exist (1) }\end{array}$ \\
\cline { 2 - 3 } & Broken Links & $\begin{array}{l}\text { Only one domain exist (0) } \\
\text { At least two domains exist (1) }\end{array}$ \\
\hline \multirow{5}{*}{ Usability } & Site Map/Table of Contents & $\begin{array}{l}\text { Exist (0) } \\
\text { Not exist (1) }\end{array}$ \\
\cline { 2 - 3 } & People with Disabilities & $\begin{array}{l}\text { Not exist (0) } \\
\text { Attainable with one click (1) } \\
\text { Exist in main page (2) }\end{array}$ \\
\cline { 2 - 3 } & Search Engine & $\begin{array}{l}\text { Not exist (0) } \\
\text { Services for people with disabilities (1) } \\
\text { Separate section (2) }\end{array}$ \\
\cline { 2 - 3 } & Language Options & $\begin{array}{l}\text { Not exist (0) } \\
\text { Exists but do not work (1) } \\
\text { Exists and works (2) }\end{array}$ \\
\cline { 2 - 4 } & $\begin{array}{l}\text { Exist only in Turkish (0) } \\
\text { Exist only in Turkish and English (1) } \\
\text { Exist in more than one language (2) }\end{array}$ \\
\hline
\end{tabular}

